\title{
Revisiting Stock Market Integration Pre-Post Subprime Mortgage Crisis: Insight From BRIC Countries
}

\author{
Chin-Hong Puaha,*, Rayenda Khresna Brahmana ${ }^{\mathrm{a}}$, Kai-Hung Wonga \\ ${ }^{a}$ Faculty of Economics and Business, Universiti Malaysia Sarawak
}

\begin{abstract}
This study revisits the long-run relationships and short-run dynamic causal linkages among BRIC stock market, with the particular attention to the 2008 subprime mortgage crisis. Extending related empirical studies, comparative analyses of pre-crisis, and post-crisis periods were conducted to comprehensively evaluate how stock market integration was affected by financial crises. In general, after employing cointegration test and VAR test, the results reveal the increase of stock market integration in BRICs after the subprime crisis. The evidence also found that China stock market is the most influential among the BRICs, in which China stock market has the ability to Granger cause the other three BRICs member countries. An important implication of our findings is that the degree of integration among countries tends to change over time, especially around periods marked by financial crises.
\end{abstract}

Keywords: Market Integration; Subprime Mortgage; Financial Crisis; BRIC

\begin{abstract}
Abstrak
Penelitian ini mengkaji ulang hubungan jangka panjang dan hubungan kausal dinamis jangka pendek antara pasar modal negara-negara BRIC, terutama pada saat krisis subprime mortgage 2008. Pengayaan studi empiris yang terkait dan analisa perbandingan sebelum-sesudah krisis dilakukan untuk mengevaluasi secara komprehensif tentang bagaimana krisis keuangan memengaruhi integrasi pasar modal. Secara umum, setelah menggunakan uji kointegrasi dan uji VAR, hasil penelitian ini memperlihatkan peningkatan integrasi pasar modal di negara-negara BRIC setelah terjadinya krisis subprime. Penelitian ini juga membuktikan bahwa pasar modal Cina adalah pasar yang paling berpengaruh di antara negara BRIC, di mana pasar modal Cina memiliki kemampuan untuk memengaruhi secara Granger Causality tiga negara anggota BRIC lainnya. Implikasi penting dari temuan kami adalah bahwa tingkat integrasi antara negara-negara cenderung berubah dari waktu ke waktu, terutama sekitar periode yang ditandai oleh krisis keuangan.
\end{abstract}

Kata kunci: Integrasi Pasar; Subprime Mortgage; Krisis Keuangan; BRIC

JEL classifications: F15; G15; G21; C32

\section{Introduction}

The development in information technology, the rise of global investors and multi-national corporations, and the relief of traditional trade barriers have facilitated the creation of global economics,

The authors acknowledge the Financial support from the Centre for Business, Economics and Finance Forecasting (BEFfore) in University Malaysia Sarawak (UNIMAS) via topdown research grant: 03(TD04)/1054/2013(02).

* Corresponding Address: Faculty of Economics and Business, Universiti Malaysia Sarawak, Kota Samarahan, 94300, Sarawak, Malaysia. E-mail: brkhresna@feb.unimas .my. and as a result, it motivates the economic integration across countries. This also leads to capital market integration where it encourages an efficient financial market through transaction cost elimination and liquidity increment. Further an integrated stock market may create global market stabilization because it shares the macroeconomics shocks.

In integrated markets, capital flows freely to where it will generate the highest return. Integrated financial markets have easier access to foreign capital, and are also more vulnerable to financial crises occurring in other areas of the world. Moreover, any increase in the degree of global financial market 
integration decreases the opportunity for diversification. It is thus essential to achieve a better understanding of the factors driving financial market integration; especially the role of macroeconomic shocks such as crisis on the integration of stock markets.

Recent years have seen considerable attention devoted to the analysis of linkages among stock markets in different countries, especially the impact of crisis to market integration. For instance, Click and Plummer (2005) documented the high integration of market after stock market crash after financial crisis 1997. This issue is an important concern for investors because greater integration among stock markets implies that reducing the opportunities for international diversification. The loss of international portfolio benefit because of crisis may attract the attention of global investors. However, interest in this topic has also been enhanced by various conclusions among integration reference and also the fact about integrated market. This research aims to revisit the crisis effect on stock market integration. Based on our knowledge, it can hardly be found a research that investigates emerging market integration due to subprime mortgage; a gap which this research aims to tackle.

Prior research provides evidence that in fully integrated markets, only global risks are priced (e.g. Solnik 1974; Sercu 1980; Adler and Dumas 1983), while in segmented markets only local risks are priced. Several empirical papers documented that national equity markets are becoming more integrated within the world market (e.g. De Jong and De Roon 2005; Carrieri et al. 2007; Pukthuanthong-Le and Roll 2008). This suggests that international equity returns are increasingly driven by global rather than by local factors. Others, such as Click and Plummer (2005), and Claessens et al. (2010), provide the dossiers of crisis impact on market integration.

Brazil, Russia, India, and China, or known as BRICs are important emerging markets for global investor. Due to its demographic and economic development, the BRIC countries are ranked among the world largest and most influential economies. The emerging market economy plays an increasingly important role in global economic development as well as monetary and financial systems. After the financial crises in Asia and Russia in 1998, Turkey and Brazil in 1999, and Argentina in 2001, the financial potential and economic development of the emerging markets especially the BRIC countries have been focused on sharply by investors (Jensen and Larsen 2004).

The development of BRIC countries stock markets are significant relative to the world economy. By referring to Table 1, the BRICs total population comprised more than 2.8 billion people which was over $40 \%$ of the world's population. Among the BRIC, China and India stood about $20 \%$ and $17 \%$ respectively. The significant grew in population could lead to the development of BRIC countries economy and directly influenced the GDP and purchasing power parity (PPP). As a result, the GDP of the BRIC had accounted for nearly $18 \%$ of the world and its GDP, PPP had stood up to $25 \%$ globally. From there, China had contributed $9.4 \%$ and $13.3 \%$ respectively. Due to high population and economy performance, the total market capitalization of the BRICs had achieved about $16 \%$ of the world. Among the BRIC, China took up the largest portion which was $8.5 \%$ of the world total market capitalization. As of 31 December 2010, China consisted of 2,062 listed companies which ranked the world's second largest by market capitalization of stocks ${ }^{1}$.

In the last decade, the BRIC countries achieved a higher economic growth rate as compared to the world, see Figure 1 Before the U.S. financial cri$\mathrm{sis}^{2}$ erupted in 2008, the BRIC countries achieved a positive high growth rate from $5 \%$ to $14 \%$. Due to this, many international investors have diversified their portfolio in the emerging market especially the BRIC countries. Table 2 reported that the foreign direct investment (FDI) inflow of BRICs increased significantly by $337 \%$ from US $\$ 77.5$ billion in 2000 to US $\$ 338.6$ billion in 2008. Even though the FDI inflow of BRICs dropped during the subprime crisis periods but due to its strong economy, it had recovered subsequently in 2010. This indicates that more and more investors have realized the importance of BRICs emerging market in world perspective and have a confidence in the BRICs market's potentiality. Therefore, it is worth to study the market integration among the BRIC countries in order

\footnotetext{
${ }^{1}$ Reported by Shang Fulin, chairman of the China Securities Regulatory Commission in China Daily dated 31 December 2010.

${ }^{2}$ The U.S. subprime mortgage crisis occurred since August 2007 due to rise of interest rate and house bubble, and this tragedy spread to the world in September 2008.
} 
Table 1: BRIC Countries - Economy and Income, 2010

\begin{tabular}{lrr|rr|rr|r|r}
\hline \multirow{2}{*}{ BRIC } & \multicolumn{2}{c}{ GDP } & \multicolumn{2}{c}{ GDP, PPP } & \multicolumn{2}{c}{ Market Capitalisation } & Population \\
\cline { 2 - 8 } & (USD billion) & $\begin{array}{r}\text { per cent } \\
\text { of world }\end{array}$ & (USD billion) & $\begin{array}{r}\text { per cent } \\
\text { of world }\end{array}$ & $\begin{array}{r}\text { (USD billion) } \\
\text { per cent } \\
\text { of world }\end{array}$ & $\begin{array}{r}\text { (million) } \\
\text { per cent } \\
\text { of world }\end{array}$ \\
\hline Brazil & 2,088 & $3.3 \%$ & 2,185 & $2.9 \%$ & 1,546 & $2.8 \%$ & 195 & $2.9 \%$ \\
Russia & 1,480 & $2.3 \%$ & 2,812 & $3.7 \%$ & 1,005 & $1.8 \%$ & 142 & $2.1 \%$ \\
India & 1,727 & $2.7 \%$ & 4,195 & $5.5 \%$ & 1,616 & $2.9 \%$ & 1,171 & $17.1 \%$ \\
China & 5,927 & $9.4 \%$ & 10,170 & $13.3 \%$ & 4,763 & $8.5 \%$ & 1,338 & $19.6 \%$ \\
\hline BRIC Total & 11,222 & $17.8 \%$ & 19,362 & $25.3 \%$ & 8,930 & $15.9 \%$ & 2,846 & $41.6 \%$ \\
\hline
\end{tabular}

Source: WDI database, World Bank

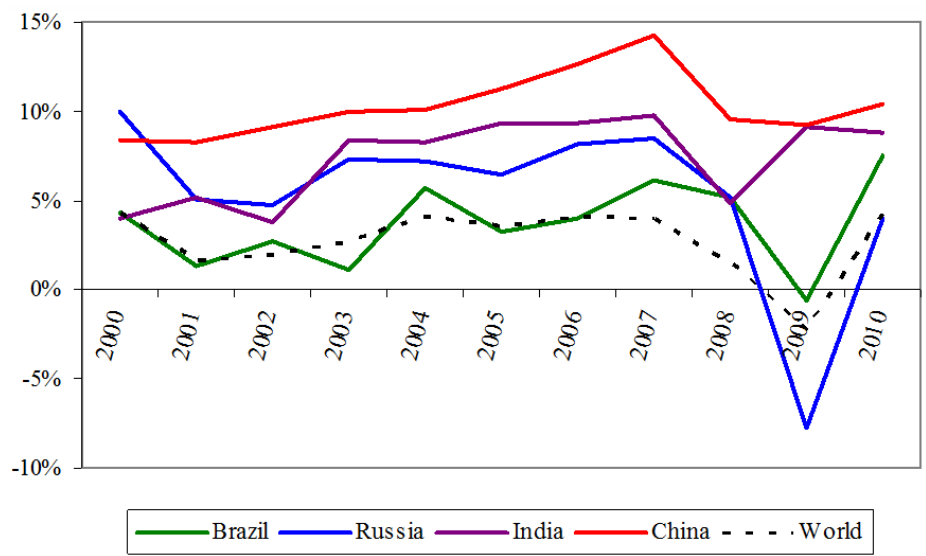

Figure 1: BRIC Countries Economic Growth, 2000-2010

Source: WDI database, World Bank 
to determine the international portfolio diversification direction.

In BRIC countries context, the issue of market integration shows various conclusion. For instance, Chittedi (2010) finds that there was a unidirectional causality from India to Russia and Brazil, and finds the existence of cointegration relationship between BRIC and developed countries. This is supported by Sheu and Liao (2011). However, An and Brown (2010) have different opinions where none of the BRIC countries has a level of cointegration with developed countries. This is in line with Syamala and Wadhwa (2012) who find the integration between US and BRIC markets not strong. Our Figure 1 also shows that there is co-movements among BRIC's stock markets, where the co-movements became more stronger after the subprime mortgage in 2008.

According to Bartlett (2008), BRIC experienced a moderate to strong growth due to the greater domestic consumption and purchasing power, expanding the trade among the BRIC countries and other emerging market, and continued inflow of foreign direct investments. On the contrary, the western economies experienced slower economic growth which had resulted in many of the investors heading to BRIC countries after the subprime mortgage crisis. As such, international portfolio investment in BRICs after the subprime mortgage crisis has become increasingly important for international investors. With that, a study of stock market integration in BRIC after the crisis is needed in order to provide clearer direction for investors on whether the subprime mortgage crisis has caused the emerging market of BRICs to be more cointegrated. Is it sensible for investors to diversify among the BRIC countries at the same time? In other words, are BRICs stock markets interdependent after the subprime crisis? Therefore, this research aims to revisit the long-run integration relationship among the stock markets of the BRIC. Further, this research also aims to analyze the shortrun causality among the stock markets of the BRIC and the possibility of the portfolio diversification among the BRIC.

The significance of the study of this topic is to provide a better view for international investors on the existence of long-run cointegration relationship among the stock markets in BRICs especially before and after the subprime crisis, where it is in- vestigated through an examination of the interrelationship and structure of linkages among the stock markets in BRICs. On the other hand, the direction of causality has also been tested to see the influences on the stock markets integration among the BRICs in the short-run in order to convey the significant policy implications to the relevant parties in making the portfolio diversification strategy decision.

\section{Literature Review}

Due to its demographic and economic development, the BRIC countries are ranked among the world largest and most influential economies. The emerging market economy plays an increasingly important role in global economic development as well as monetary and financial systems. After the financial crises in Asia and Russia in 1998, Turkey and Brazil in 1999, and Argentina in 2001, the financial potential and economic development of the emerging markets especially the BRIC countries have been focused on sharply by investors (Jensen and Larsen 2004).

The growth of stock market in BRIC has brought up an interest to the policymakers by expanding the financing options availability. As fast-growing emerging markets, BRIC countries are one of the options to have portfolio gain for global investors. Therefore, literature regarding the integration of BRIC countries is interesting and important in international finance study (see the review of Chittedi 2010).

The fluctuation of BRIC's economy may result in a cost of portfolio benefit. Crisis for instance, may reduce the portfolio benefit because nowadays one country is closely related to other countries activity. Gwinner and Sanders (2010) conclude that the subprime crisis had huge impact on BRIC countries. This is supported by other empirical papers such as Kregel (2009), Ghosh and Chandrasekhar (2009), and Claessens et al. (2010). Kregel (2009), for instance, documents that the global crisis might affect the economic development of BRIC countries and loosen the persona of their international diversification benefits. Ghosh and Chandrasekhar (2009) find that there was a cost of coupling of global crisis to India's economy. In a wider sample, Claessens et al. (2010) show the role of fi- 
Table 2: BRICs Foreign Direct Investment Inflow, 2000-2010

\begin{tabular}{rrrrrr}
\hline \multirow{2}{*}{ Year } & Brazil & Russian & India & China & Total \\
\cline { 2 - 5 } & \multicolumn{5}{c}{ US\$ Million } \\
\hline 2000 & 32,779 & 2,714 & 3,584 & 38,399 & 77,476 \\
2001 & 22,457 & 2,748 & 5,472 & 44,241 & 74,918 \\
2002 & 16,590 & 3,461 & 5,626 & 49,308 & 74,985 \\
2003 & 10,144 & 7,958 & 4,323 & 47,077 & 69,502 \\
2004 & 18,166 & 15,444 & 5,771 & 54,936 & 94,317 \\
2005 & 15,066 & 12,886 & 7,606 & 117,208 & 152,766 \\
2006 & 18,782 & 29,701 & 20,336 & 124,082 & 192,901 \\
2007 & 34,585 & 55,073 & 25,483 & 160,052 & 275,193 \\
2008 & 45,058 & 75,002 & 43,406 & 175,148 & 338,614 \\
2009 & 25,949 & 36,500 & 35,596 & 114,215 & 212,260 \\
2010 & 48,438 & 42,868 & 24,159 & 185,081 & 300,546 \\
\hline Source: Databank, World Bank
\end{tabular}

nancial crisis to BRIC economy, and each BRIC countries had different impact of financial crisis, especially the subprime mortgage crisis. One of the examples, Brazil stock market, declined $50 \%$ in 6 months during the subprime mortgage crisis tragedy, and needed 2 years of recovery. This is similar to the India stock markets, where it was very sensitive to the financial crisis. During the subprime mortgage, India stock markets declined rapidly up to more than $50 \%$, yet expanded back doubling the index after adapting to the crisis condition. However, it was hit back again due to the European sovereign debt crisis, and contracted again to weaken $30 \%$ in 2 months. Different with the previous 2, Russia and China stock markets were more prudent to crisis. Even though the market dropped for 6 months, due to its reserves, these two stock markets recovered rapidly. These dossiers portray that each BRIC country has had different persistence of handling and disseminating subprime mortgage crisis. Hence, it is an intriguing question to know how a crisis would affect BRIC's stock market and its integration to other stock markets during the subprime mortgage.

Recent literatures (i.e. Bhar and Nikolova 2009; Chittedi 2010; Kenourgios, Samitas and Paltalidis 2011) conclude that the integration among BRICs countries has become stronger and stronger due to their financial development and economic liberalization. However, due to the subprime mortgage crisis in 2008, the integration is getting weak because each BRIC country has different and unique relationship to developed countries (see Gwinner and Sanders 2010; Kregel 2009; Ghosh and Chandrasekhar 2009; Claessens et al. 2010).
Chittedi (2010) investigates the long-run equilibrium relationship among the BRICs and three major developed countries (US, UK, and Japan). The daily stock market indexes from NASDAQ, FTSE100, Nikkei-225, BOVESPA, Moscowtimes, Sensex and Shanghai Stock Exchange ranging from January 1998 to August 2008 are used. He discovers that there was a unidirectional causality from India to Russia and Brazil, and finds the existence of cointegration relationship between BRICs and developed countries (see also Sheu and Liao 2011). Sheu and Liao (2011) further document that in the short-run, there is a bilateral causality between US with Russia and China but unilateral causality from US to India and from Brazil to US.

However, An and Brown (2010) have different opinion. Based on the sample periods from October 1995 to October 2009, they notice that apart from China, none of the BRIC countries had a level of cointegration with the US economy. The result is conformed to the study by Syamala and Wadhwa (2012). According to Syamala and Wadhwa (2012), the degree of correlation was varied between the US and BRICs markets, and the correlation among the markets returns was not strong. Cointegration between US and India was weak but China and Russia stock markets were interdependent on US stock market. Meanwhile, Brazil stock market was not influenced by US as well as other BRIC nations. Based on their findings, the global investors have an opportunity to gain from the portfolio diversification in BRIC countries which has a lower cointegration with US stock market.

Fahami (2011) incorporates the subprime crisis to examine its impact towards BRIC and devel- 
ops countries stock market linkages. The period of analysis is divided into pre-crisis (Jan 10, 2005Jul 22, 2007), during crisis (Jul 29, 2007-Jan 10, 2010) and post-crisis (Jan 11, 2010-Jul 21, 2011). Weekly closing stock indexes data are obtained from seven prominent stock indexes of BOVESPA, RTS, S\&P CNX 500, SSE Composite, S\&P 500, FTSE 100 and Nikkei 500. The findings reveal an increased causality relationship among the BRICs and developed countries during the subprime crisis. She further finds that China was the most influential stock market before the crisis and US influenced most of the major equity markets during the crisis except for China and India.

Meanwhile, Gupta (2011) also studies the dynamic relationship of the BRICs stock markets in the financial turmoil context. The daily closing indexes from January 2008 to November 2011 are adopted based on Brazil (IBOVESPA), Russian (RTSI), India (S\&P CNX Nifty) and China (SCl). The empirical results reveal that there was unidirectional causality from Russia, India, and China to Brazil, and India to Russia. However, China economy had bidirectional causality with Russia and India economy. He concludes that the Chinese economy was largely interdependent on Indian and Russian economy. Therefore, it can be hypothesized that there is stock market integration among BRIC countries, where global investors may not achieve portfolio diversification benefit by adding BRIC countries in the same basket.

\section{Method}

\subsection{Data}

In analyzing the structure of linkages and causal relationship among the stock markets in BRICs, four prominent national stock markets are selected, namely Brazil BOVESPA Index, Russia Moscow Times Index, India Bombay SE 100 Index, and China Shanghai Composite Index. All series are transformed into natural logarithm form. The full sample period covers the period of 2003 to 2012. Data on daily closing stock indexes are gathered from Datastream covering the periods of precrisis (2003 to 2008) and post-crisis (2008-2012). These relatively shorter periods are selected because we intend to analyze the relationship be- tween BRICs stock markets in the midst of subprime crisis.

\subsection{Methodology}

Overall, the estimation model follows prior research where the integration is examined under long-run and short-run relationship. Firstly, this study has employed the Augmented Dickey-Fuller (ADF) unit root test to examine the order of integration for the stock markets data in the BRICs in order to check whether the examined data are stationary or not. To test the integration, this research employs Johansen and Juselius (1990) test, which develops multivariate approach for testing long-run cointegration among a set of non-stationary variables. This estimation model is important to evaluate the existence of long-run stock market linkages among the BRICs. In order to examine the short-run relationships, this research runs Granger causality test. It is developed to test the direction and significance of causality among BRICs stock markets. According to Granger (1969), variable X is said to Granger cause the variable $Y$ if past value of $X$ could better predict $Y$ after the controlling for past value of $Y$, or equivalently if the coefficients on the lagged value of $X$ are statistically significant. The Granger causality test is determined into three types: unidirectional for both stock markets; bidirectional across the markets; or none of the relationship exists.

\section{Result and Analysis}

\subsection{Unit Root Test Results}

Finance research usually uses time series data, which are assumed to be stationary. Using nonstationary data in regression analysis leads to spurious regression results. We apply the Augmented Dickey Fuller (ADF) of the unit root test to determine whether the stock market data of BRICs are stationary. Table 3 shows the ADF test results.

This test allows this research to gauge the robustness of the integration properties of market integration. The null hypothesis is that $Y t$ has aunit root (non-stationary), that is $H 0: \alpha 2=0$, versus the alternative hypothesis that $Y t$ is stationary or 
$H 1: \alpha 2<0$. Table 3 shows the results of the unit root test. Comparing the calculated ADF statistic to MacKinnon (1991) critical value, we conclude that we fail to reject the null hypothesis as most of the variables in the level contain unit root or not stationary for both pre and post crisis of market integration properties. It indicates that all variables are integrated and have long-run co-movement indication. Therefore, we continue the procedure for the co-integration test.

\subsection{Cointegration Test Results}

Since the time series have been confirmed as stationary at first difference in unit root test, now we can proceed to examine the long-run cointegration relationship among the stock markets in BRICs by using the Johansen-Juselius cointegration test. The significance of Johansen and Juselius cointegration vector is determined through the maximum likelihood based on the trace and maximum eigenvalue statistics. To test this cointegration or longrun relationship, we employ the maximum likelihood approach of Johansen (1988) based on a vector autoregressive model:

$$
X_{t}=\mu+\Pi_{1} X_{t-1}+\cdots+\Pi_{k} X_{t-k}+\varepsilon_{t}
$$

Where $X_{t}$ is the vector variables integrated in the same order; $\mu$ is the intercept terms for the vector, $\Pi$ is the coefficient matrix, and $\varepsilon_{t}$ is the error terms which are assumed to be white noise. This equation equivalently states in the following cointegration regressions:

$$
Y_{t}=\beta_{0}+\beta_{1} X_{t}+v_{t}
$$

Where the null hypothesis is that $Y_{t}$ and $X_{t}$ are not cointegrated. The specification of the trace test and maximum eigenvalue test are provided under Fraser and Oyefeso (2005) below:

$$
\lambda_{\text {trace }}(r)=-T \sum_{i=r+1}^{p} \ln (1-\lambda)
$$

where $\lambda_{\text {trace }}$ is the estimated trace value, $T$ is the number of observation and $p$ is the number of variables.

The results of the cointegration test are documented in Table 4. It clearly indicates that there is no cointegration between the BRIC in precrisis period as we fail to reject the null hypothesis of non-cointegration. This means there is no co-movement or market integration among BRIC countries in the long-run before the subprime mortgage implying global investor might achieve portfolio diversification by adding BRIC countries in their baskets. This is in line with prior researches such as Chittedi (2010), and Xu and Hamori (2012), which conclude there is no market integration among BRIC countries.

However, two cointegration equations are found in the post-crisis period for both trace and maximum eigenvalue test, hence, we can reject the null hypothesis $r \leqslant 1$ at five percent level of significance. Thus, we conclude that the cointegration among the BRIC stock markets has increased after the occurrence of US subprime crisis event in 2008. This indicates that some of the BRIC countries are tied with one another in the long-run, therefore, the portfolio diversification opportunities have been diminishing through time. This is consistent with previous researches such Click and Plummer (2005), Huyghebaert and Wang (2010), and Kenourgios, Samitas and Paltalidis (2011), which conclude that stock market becomes more integrated after a financial crisis event.

\subsection{Granger Causality Test Results}

We proceed with the Granger Causality test in order to investigate the short-run dynamic comovement among BRIC's market integration. In general, the Granger Causality test is one that can determine whether one variable is useful in forecasting another variable by revealing its causality. Despite there is a long-run relationship among the BRICs stock markets, the causality directional test should be conducted to confirm the short-run linkages and its causal direction. Table 5 shows the results from Granger causality test based on VECM among the stock markets in BRICs before and after the subprime crisis. The empirical results reveal that the BRICs stock market linkages have been established in post-crisis period with the presence of unidirectional and bidirectional causality. The results support the findings of An and Brown (2010), Fahami (2011), Sheu and Liao (2011) who also incorporate the effect of subprime crisis to the level of integration among the BRICs stock markets. 
Table 3: BRICs Foreign Direct Investment Inflow, 2000-2010

\begin{tabular}{|c|c|c|c|c|c|}
\hline \multirow{3}{*}{ Countries } & \multirow{3}{*}{ Test Equation } & \multicolumn{2}{|c|}{ Pre-Crisis } & \multicolumn{2}{|c|}{ Post-Crisis } \\
\hline & & \multicolumn{4}{|c|}{ ADF (AIC) } \\
\hline & & Level & 1st difference & Level & 1st difference \\
\hline \multirow{2}{*}{ Brazil } & Trend \& Intercept & $-3.080(0)$ & $-7.459(0) a$ & $-3.769(4) b$ & $-4.358(0) \mathrm{a}$ \\
\hline & Intercept & $-0.790(0)$ & $-7.494(0) a$ & $-1.790(1)$ & $-4.353(0) a$ \\
\hline \multirow{2}{*}{ Russia } & Trend \& Intercept & $-1.853(0)$ & $-7.910(0) a$ & $-2.993(1)$ & $-3.345(0) c$ \\
\hline & Intercept & $-0.881(0)$ & $-7.984(0) a$ & $-2.263(1)$ & $-3.222(0) b$ \\
\hline \multirow{2}{*}{ India } & Trend \& Intercept & $-4.392(2) a$ & $-4.304(5) a$ & $-3.575(4) b$ & $-4.903(0) a$ \\
\hline & Intercept & $-1.824(0)$ & $-4.320(5) a$ & $-2.168(4)$ & $-4.859(0) a$ \\
\hline \multirow{2}{*}{ China } & Trend \& Intercept & $-3.949(10) b$ & $-2.011(3)$ & $-2.876(0)$ & $-6.092(0) a$ \\
\hline & Intercept & $-3.096(10) b$ & $-2.198(3)$ & $-3.737(5) a$ & $-6.015(0) a$ \\
\hline
\end{tabular}

Notes: (c), (b), (a) denote as significant level at $10 \%, 5 \%$ and $1 \%$ levels respectively.

The lag length selections show in parentheses are determined through the Akaike Information Criterion (AIC).

The ADF test examines the null hyphothesis of unit root (non-stationary) against the alternative hyphothesis of no unit root (stationary).

Source: Author's estimate.

Table 4: Johansen-Juselius Cointegration Test Results

\begin{tabular}{|c|c|c|c|c|c|}
\hline \multicolumn{2}{|c|}{ Lag intervals: 12} & \multicolumn{4}{|c|}{ Pre-crisis } \\
\hline \multirow[t]{2}{*}{$H_{0}$} & \multirow[t]{2}{*}{$H_{1}$} & \multicolumn{2}{|c|}{$\lambda_{\text {trace }}$} & \multicolumn{2}{|c|}{$\lambda_{\max }$} \\
\hline & & Statistic & Probability & Statistic & Probability \\
\hline$r=0$ & $r=1$ & 38.879 & 0.265 & 16.989 & 0.581 \\
\hline$r \leqslant 1$ & $r=2$ & 21.891 & 0.305 & 13.477 & 0.409 \\
\hline$r \leqslant 2$ & $r=3$ & 8.414 & 0.422 & 7.716 & 0.408 \\
\hline \multicolumn{2}{|c|}{ Lag intervals: 12} & \multicolumn{4}{|c|}{ Post-crisis } \\
\hline \multirow[t]{2}{*}{$H_{0}$} & \multirow[t]{2}{*}{$H_{1}$} & \multicolumn{2}{|c|}{$\lambda_{\text {trace }}$} & \multicolumn{2}{|c|}{$\lambda_{\max }$} \\
\hline & & Statistic & Probability & Statistic & Probability \\
\hline$r=0$ & $r=1$ & 60.577 & $0.002^{* \star *}$ & 30.293 & $0.022^{* *}$ \\
\hline$r \leqslant 1$ & $r=2$ & 30.284 & $0.044^{\star \star}$ & 22.497 & $0.032^{\star *}$ \\
\hline$r \leqslant 2$ & $r=3$ & 7.787 & 0.489 & 5.379 & 0.693 \\
\hline
\end{tabular}

Notes: $\left(^{* *}\right),\left(^{* * *}\right)$ denote as significant level at $5 \%$ and $1 \%$ levels respectively.

Source: Author's estimate.

Table 5: Johansen-Juselius Cointegration Test Results

\begin{tabular}{|c|c|c|c|c|c|c|c|c|}
\hline \multicolumn{9}{|c|}{ Lag interval: 12} \\
\hline \multirow{3}{*}{ Countries } & \multicolumn{4}{|c|}{ Pre-Crisis } & \multicolumn{4}{|c|}{ Post-Crisis } \\
\hline & Brazil & Russia & India & China & Brazil & Russia & India & China \\
\hline & \multicolumn{4}{|c|}{$X^{2}$ - statistic (p-value) } & \multicolumn{4}{|c|}{$X^{2}$ - statistic (p-value) } \\
\hline Brazil & - & 2.613 & 1.894 & 1.014 & - & $13.130^{\star * *}$ & $16.536^{\star \star \star}$ & $11.190^{\star \star *}$ \\
\hline Russia & 0.714 & - & $6.231^{* *}$ & 0.507 & $9.961^{* * *}$ & - & $19.225^{\star \star \star}$ & $8.265^{* *}$ \\
\hline India & 2.059 & 0.523 & - & 1.811 & 2.456 & $13.165^{\star * *}$ & - & $17.241^{\star * *}$ \\
\hline China & 1.338 & 1.130 & 0.181 & - & 0.0454 & 4.490 & 1.727 & - \\
\hline
\end{tabular}

Notes: $\left(^{* *}\right),\left({ }^{* * *}\right)$ denote as significant level at $5 \%$ and $1 \%$ levels respectively. Lag length is chosen based on AIC.

Source: Author's estimate. 


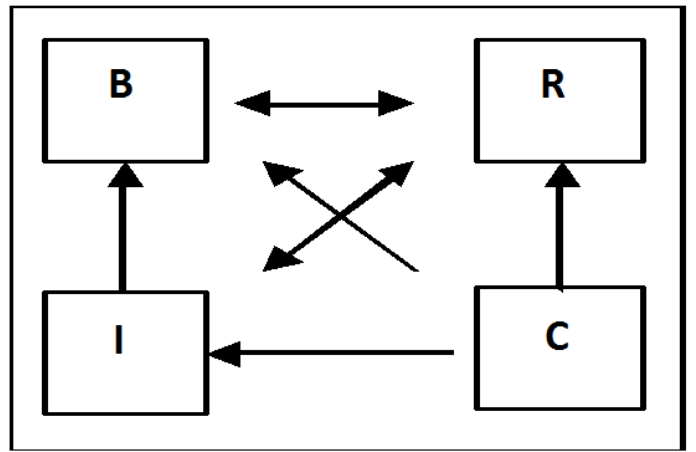

Notes: B denotes Brazil, $\mathbf{R}$ denotes Russia, I denotes India and $\mathbf{C}$ denotes China.

The symbol of $\longrightarrow$ represents the unidirectional Causality, while $\longleftrightarrow$ represents bidirectional causality

Figure 2: Direction of Causality

Source: Author's estimate

Through the Granger causality test, we note that the obtained results consist of four unidirectional causalities and two bidirectional relationship among the BRICs. The results reveal that there is a unidirectional causality from India to Brazil, and from China to all other BRIC countries. Meanwhile, the bidirectional causality between Brazil and Russia, and India and Russia exists. Among the BRICs, China is the most independent stock market but Brazil stock market has the least influence. See Figure 2 for more detailed results of Granger causality.

\section{Discussion}

Since 2000, China and other BRICs countries economic performance had proved themselves to have a better position in the world perspective. From 2000 to 2008, the BRICs had accounted for $30 \%$ of the global increased output. During this period of time, BRICs had shared the rise of $16 \%$ to $22 \%$ relative to the world economic output, in which China had contributed more than half to this growth ${ }^{3}$. Low labour cost and large domestic market were the main competitive advantages that brought China's economy to the world's second largest in 2010. Under Hu Jintao ${ }^{4}$ administration, many of China's foreign policies had changed and pursued more aggressively. He included more diverse alliance countries like Canada, Australia,

\footnotetext{
${ }^{3}$ Detailed discussions refer to Global Sherpa.

${ }^{4} \mathrm{Hu}$ Jintao is the China's President since 2003 until present.
}

Iran and Venezuela in order to increase its power. With an unprecedented shortage of natural resources, China has invested heavily in countries rich in resources such as Australia, Africa, Brazil, Pakistan and South Asia to secure access to mineral right. With the multipolar world practice, China has developed and tied with all the major power and regional blocs to foster their relationship. With this, China has had the same official position with the US on terrorism issue. Besides that, China has also increased its economic interactions with Asian countries and rebuilt its image as regional leader. In BRIC nations, China has exerted relatively greater influence after the subprime crisis due to its continuously spectacular economic development with the support of rich natural and labour resources in the countries. Massive influx of FDI by foreign investor seeks to China as a platform, by utilizing its cheaper resources, to manufacture and sell in China as well as foreign markets (Chow 2010).

In the meantime, India has served to accelerate the economic growth since after the economic liberalization in 1990s. The trade globalization has expanded India's two-way trade (merchandise exports plus imports) which deepens the financial integration of India to the world and puts India to appear to be an important trading partner (Misra 2009). Due to the strong population and domestic consumption growth, both China and India economy are becoming increasingly important in relation to the world.

Over the past few years, the large number of investments have flowed into Brazil due to the coun- 
try's strong economic background as well as economic policies and programs in controlling taxes and public investment. Brazil investments have been so attractive to global investors because oversea investor can enjoy the same rights as the domestic investors have with the availability of high return, buoyant and growing market. In 2000s, Brazil became the largest and most powerful countries in South America. With the large population, vast territory, and abundant resources in agricultural and mining, Brazil economy had a chance to stand in a strong position in global economy. As of 2011, Brazil was still the world leader in exporting of iron ore and foodstuffs. Since April 2009, China started to overtake the US and became Brazil's largest trading partner ${ }^{5}$. In 2011, the records show that, Brazil-China goods trade amounted to US $\$ 77$ billion which was $28 \%$ more than Brazil-US of US $\$ 60$ billion. Therefore, this is an evidence of increased stock markets integration between China and Brazil and unidirectional causality from China to Brazil after the subprime crisis.

After the dissolution of Soviet Union, a development of new economic model in Russia has been achieved rapidly. With its large territory and rich natural resources, Russia has become one of most developing and attractive economy in the world. Russia has been one of the largest natural gas producer as well as exporter in the world. In 2011, $35 \%$ of the world's gas belonged to Russia ${ }^{6}$. In 2010, China overtook Germany as Russia's largest trading partner. With the bilateral trade, China imports crude oil and gas from Russia as an input to produce equipments back to Russia. This bilateral trade agreement has fostered the integration between China and Russia. Therefore, this evidence has supported our finding of an increasing integration between Russia and China after the subprime crisis. Besides that, the unique geographical position, technological advancement, attractive tax system, extensive government support with stable social and political system have made Russia an attractive country after the subprime crisis.

\footnotetext{
${ }^{5}$ Details description refers The Telegraph.

${ }^{6}$ Major discussion refers Ministry of Economic Development of Russian Federation.
}

\section{Conclusion}

This research examines the stock market integration among BRICs emerging market namely, Brazil, Russia, India, and China. The long-run cointegration and short-run causality among the BRICs stock markets are investigated in order to provide the empirical evidences of portfolio diversification opportunities to the investor in BRICs particularly after the US subprime mortgage crisis. Unit root, cointegration, and casuality testing procedures are adopted to analyze the monthly data covering the periods from 2003 to 2012 .

The findings reveal an increase of long-run integration of the BRICs stock markets over the postcrisis period through the adoption of JohansenJuselius cointegration test. The Granger causality results also indicate an increasing linkages among the BRICs stock markets after the subprime crisis with significant changes in causality directions. From that, India is Granger causes the Brazil whereas China leads all the other BRIC countries but none of them influence China. Meanwhile, there is bidirectional causality existing between Brazil and Russia, and India and Russia. In summary, China iss found to be the most influential stock market while Russia and Brazil stock market performance are largely interdependent to other BRICs markets.

In connection to our findings, the important implication is that the degree of stock market integration and causalities direction among the countries tends to change over time especially after the financial crisis (see, for example, Lim 2007; Yang et al. 2003; Bekaert and Harvey 1995). This important implication is crucial for monetary and financial authorities in response to the financial crises in order to implement appropriate policies for financial stability. This implication is also useful for the regional investors in managing the risk of investment whereby to gain the greatest benefits through the portfolio diversification strategies.

As a result of the integration of stock markets in $B R I C$ region in the long-run, the potential of obtaining the abnormal profit through portfolio diversification in BRICs is limited because the abnormal profit will be arbitraged away in the long-run. Therefore, the international investor may invest in BRICs stock markets up to some extent in order to diversify the 
risk and earn the abnormal returns in the long-run. Nevertheless, the investor still can benefit from the short-run linkage that exists between some of the BRICs stock markets.

\section{References}

[1] Adler, M \& Dumas, B 1983, 'International Portfolio Choice and Corporation Finance: A Synthesis', Journal of Finance, vol. 38, no. 3, 925-984.

[2] An, L \& Brown, D 2010, 'Equity Market Integration Between the US and BRIC Countries: Evidence from Unit Root and Cointegration', Research Journal of International Studies, vol. 1, no. 16, 15-24.

[3] Bartlett, D 2008, Economic Trends in the BRIC Countries, Finance Director Europe, April 7th.

[4] Bekaert, G \& Harvey, CR 1995, 'Time-varying World Market Integration', The Journal of Finance, vol. 50, no. 2, 403-444.

[5] Bhar, R \& Nikolova, B 2009, 'Return, Volatility Spillovers and Dynamic Correlation in the BRIC Equity Markets: an Analysis Using a Bivariate EGARCH Framework', Global Finance Journal, vol. 19, no. 3, 203-218.

[6] Carrieri, F, Errunza, V, \& Hogan, K 2007, 'Characterizing World Market Integration through Time', Journal of Financial and Quantitative Analysis, vol. 42, no. 4, 915-940.

[7] Chittedi, KR 2010, 'Global Stock Markets Development and Integration: with Special Reference to BRIC Countries', International Review of Applied Financial Issues and Economics, vol. 1, 18-36.

[8] Chow, D 2010, 'China's Response to the Global Financial Crisis: Implications for U.S.-China Economic Relations', Global Bussiness Law Review, vol. 1, 47-81.

[9] Claessens, S, Dell'Ariccia, G, Igan, D, \& Laeven, L 2010 'Cross-country Experiences and Policy Implications from Tthe Global Financial Crisis', Economic Policy, vol. 25, no. 62, 267-293.

[10] Click, RW \& Plummer, MG 2005, 'Stock Market Integration in ASEAN After the Asian Financial Crisis', Journal of Asian Economics, vol. 16, no. 1, 5-28.

[11] De Jong, F \& de Roon, FA 2005, 'Time-varying Market Integration and Expected Returns in Emerging Markets', Journal of Financial Economics, vol. 78, no. 3, 583-613.

[12] Fahami, NA 2011, 'The Structure of Linkages and Causal Relationship Between BRIC and Developed Equity Markets', International Conference on Information and Finance, IPEDR, vol. 21, 72-77.

[13] Fraser, P \& Oyefeso, O 2005, 'US, UK and European Stock Market Integration', Journal of Business Finance \& Accounting, vol. 32, no. 1-2, 161-181.

[14] Ghosh, J \& Chandrasekhar, CP 2009, 'The Costs of 'Coupling': the Global Crisis and the Indian Economy', Cambridge Journal of Economics, vol. 33, no. 4, 725-739.

[15] Granger, CW 1969, 'Investigating Causal Relations by Econometric Models and Cross-spectral Methods', Econometrica: Journal of the Econometric Society, vol. 37, no. 3, 424-438.

[16] Gupta, S 2011, 'Study of BRIC Countries in the Financial Turmoil', International Affairs and Global Strategy, vol. 1, $1-15$.

[17] Gwinner, WB \& Sanders, AB 2010, The Subprime Crisis: Implications for Emerging Markets', in Lessons from the
Financial Crisis: Causes, Consequences, and Our Economic Future, ed RW Kolb , pp. 559-568.

[18] Huyghebaert, N \& Wang, L 2010, 'The Co-movement of Stock Markets in East Asia: Did the 1997-1998 Asian Financial Crisis Really Strengthen Stock Market Integration?', China Economic Review, vol. 21, no. 1, 98-112.

[19] Jensen, TH \& Larsen, JAK 2004, 'The BRIC Countries', Danmarks Nationalbank Monetary Review 4th Quarter, 39.

[20] Johansen, S 1988, 'Statistical Analysis of Cointegration Vectors', Journal of Economic Dynamics and Control, vol. 12, no. 2, 231-254.

[21] Johansen, S \& Juselius, K 1990, 'Maximum Likelihood Estimation and Inference on Cointegration with Applications to the Demand for Money', Oxford Bulletin of Economics and Statistics, vol. 52, no. 2, 169-210.

[22] Johansen, S 1992, 'Testing Weak Exogeneity and the Order of Cointegration in UK Money Demand Data', Journal of Policy Modeling, vol. 14, no. 3, 313-334.

[23] Kenourgios, D, Samitas, A, \& Paltalidis, N 2011, 'Financial Crises and Stock Market Contagion in a Multivariate TimeVarying Asymmetric Framework', Journal of International Financial Markets, Institutions and Money, vol. 21, no. 1, 92-106.

[24] Kregel, J 2009, 'The Global Crisis and the Implications for Developing Countries and the BRICs: is the "B" Really Justified?', Revista de Economia Política, vol. 29, no. 4, 341-356.

[25] Lim, LK 2007 December, Linkages Between ASEAN Stock Markets: A Cointegration Approach', in MODSIM 2007 International Congress on Modelling and Simulation. Modelling and Simulation Society of Australia and New Zealand, pp. 1818-1824.

[26] MacKinnon, J 1991, Critical Value for Cointegration Tests for in RF Engle and CWJ Granger, Long-run Economic Relationships.

[27] Misra, BM 2009, 'Global Financial Crisis and Monetary Policy Response: Experience of India'. Paper presented at the workshop on 'Strengthening the Response to the Global Financial Crisis in Asia-Pacific: The Role of Monetary, Fiscal and External Debt Policies, United Nations Economic and Social Commission for Asia and the Pacific, Dhaka, Bangladesh, July 2009.

[28] Pukthuanthong-Le, K \& Roll, R 2008, Real Interest Rates, Expected Inflation, and Real Estate Returns: A Comparison of the US and Canada. Retrieved July, 30, 2009.

[29] Sercu, P 1980, 'A Generalisation of the International Asset Pricing Model', DTEW Research Report 8002.

[30] Sheu, HJ \& Liao, CH 2011, 'Dynamics of Stock Market Integration between the US and the BRIC. African Journal of Business Management, vol. 5, no. 9, 3674-3689.

[31] Solnik, BH 1974, 'An Equilibrium Model of the International Capital Market', Journal of Economic Theory, vol. 8, no. 4, 500-524.

[32] Syamala, SR \& Wadhwa, K 2012, 'International Stock Market Integration: A Study of the US and the BRIC Markets', Research Journal of Economics and Business Studies, vol. 1, no. 3, 3-10.

[33] Xu, H \& Hamori, S 2012, 'Dynamic Linkages of Stock Prices Between the BRICs and the United States: Effects of the 2008-09 Financial Crisis', Journal of Asian Economics, vol. 23, no. 4, 34-352.

[34] Yang, J, Kolari, JW, \& Min, I 2003, 'Stock Market Integration and Financial Crises: the Case of Asia', Applied Financial Economics, vol. 13, no. 7, 477-486. 